\title{
Response of incomplete Tifton 9 bahiagrass stands to reno- vation
}

\author{
R.N. GATES
}

Author is research agronomist, Crop Genetics and Breeding Research Unit, USDA-ARS, Coastal Plain Experiment Station, Tifton, Ga. 31793.

\begin{abstract}
Establishment of warm-season grasses from seed is often impeded by slow germination and emergence, and low seedling vigor. Stand development can be further retarded by unfavorable soil moisture resulting from high temperatures and erratic precipitation. Management of poorly established stands of warmseason grasses has received limited research attention. Two- or 3year old, poorly established stands (basal occupation < 61\%) of 'Tifton 9' bahiagrass (Paspalum notatum Flügge var. saure) at a dry upland site and at a moist lowland site were reseeded $(5.6 \mathrm{~kg}$ $\mathrm{ha}^{-1}$ ) in April of 2 different years either without tillage or after rototilling or light disking and compared to a non-seeded control. Our objective was to determine whether any combination of tillage and/or seeding would enhance stand coverage. At the upland site, basal occupation of the control increased from an initial 61 to $80 \%$. No benefit was derived from interseeding, and both tillage treatments resulted in a stand reduction $(P<0.05)$ after 1 year. At the lowland site, basal occupation increased from an initial 28 to $59 \%$ for the control. Similar responses were observed with renovation treatments, but none were greater $(P>$ 0.05) than the control. Bahiagrass stands with at least a few plants per $\mathrm{m}^{2}$ should be managed to minimize weed encroachment, but introducing additional seed, with or without tillage, offered no benefit.
\end{abstract}

Key Words: establishment, reseeding, tillage, Paspalum notatum

Establishment of warm-season grasses is made difficult by several factors. Erratic precipitation and high temperatures at planting or soon after can lead to soil moisture conditions unfavorable for germination, emergence and seedling survival. Ries and Hoffman (1996) indicate that, in the Northern Plains, stand failures can result for any planting date in a given year. Considerable recent research has examined planting management in the Northern and Central Plains and mid-Atlantic, particularly herbicide use, in establishing several warm-season grass species including: big bluestem [Andropogon gerardii Vitman], sand bluestem [Andropogon gerardii var. paucipilus (Nash) Fern], prairie sandreed [Calamovilfa longifolia Hook.], switchgrass [Panicum virgatum L.], indiangrass [Sorghastrum nutans (L.) Nash], sideoats gramma [Bouteloua curtipendula (Michx.)Torr.], little bluestem [Schizachyrium scoparium (Michx.) Nash], and blue gramma [Bouteloua gracilis (H.B.K.) Lag ex Steud.]

\footnotetext{
Joint contribution of USDA-ARS, and Univ. of Georgia Coastal Plain Experiment Station.

Manuscript accepted 7 Mar. 2000.
}

\section{Resumen}

El establecimiento de zacates de estación caliente a partir de semilla a menudo se dificulta por la lenta geminación y emergencia y el bajo vigor de las pl-ntulas. El desarrollo de la población puede ser aun mas retardado por condiciones desfavorables de humedad del suelo que resultan de las altas temperaturas y la precipitación err-tica. La investigación sobre manejo de praderas de zacates de estación caliente establecidas pobremente ha recibido poca atención. Praderas de 'Tifton 9' "Bahiagrass" (Paspalum notatum Fl,gge var. Saure) mal establecidas (Ocupación basal < 61\%) de 2 a 3 años de antigsedad y situadas en un sitio seco $y$ uno $h$ medo se resembraron $\left(5.6 \mathrm{~kg} \mathrm{ha}^{-1}\right)$ en abril de 2 diferentes años sin practicas de labranza y después de barbechar y rastrear ligeramente el terreno y se compararon con praderas control sin resiembra. Nuestro objetivo fue determinar si alguna combinación de labranza y/o siembra mejoraráa la cobertura de la pradera. En el sitio seco, la cobertura basal de las praderas control se incremento de $61 \%$ inicial a $80 \%$. La intersiembra no produjo beneficios adicionales y ambos tratamientos de labranza redujeron la cobertura de la pradera $(P<0.05)$ después de un año. En el sitio h medo, en las praderas control, la cobertura basal aumentó del $28 \%$ inicial a $59 \%$, se observó una respuesta similar con los tratamientos de renovación, pero ninguno fue mayor $(P>0.05)$ que el control. Las praderas de 'Bahiagrass", con al menos unas pocas plantas por $\mathbf{m}^{2}$, deben ser manejadas para minimizar la invasión de maleza y la adición de semilla, con o sin practicas de labranza, no produce beneficio alguno.

(Bahler et al. 1990, Beckman et al. 1993, Hintz et al. 1998, Masters et al. 1990, McKenna and Wolf 1990, Ries and Hofmann 1996, Vassey et al. 1985, Vogel 1987).

Though total annual precipitation is greater in the southeastern U.S. than in the Great Plains, precipitation in summer can be erratic and periods of drought associated with high temperatures occur frequently enough to make warm-season grass establishment uncertain in this region as well. Bahiagrass (Paspalum nota tum Flügge var. saure), widely used for pasture in the humid southeastern U.S., germinates slowly (West and Marousky 1989) and emerged seedlings are sensitive to competition (Beaty and Powell 1978, Williams and Webb 1958). While a number of factors related to establishment, including planting date, seed treatment, dehulling, and planting rate have been considered, only extremely high seeding rate promoted more rapid establishment (Gates and Mullahey 1997, Gates and Dewald 1998). Even when every effort is made to ensure stand establishment, weather extremes may limit success. Poor establishment frequently results 
in variable stands with open areas. Options in this situation include: 1) doing nothing, 2) renovation through some combination of seeding and tillage, and 3 ) complete seedbed preparation and reseeding — still facing the same possibility of success or failure.

While considerable effort has been directed at the initial establishment of warm-season grasses, including bahiagrass, management options to improve poor stands have not been considered. Plots consisting of relatively open stands of bahiagrass from previous research provided an opportunity to examine the response of 'Tifton 9' bahiagrass stands to renovation treatments. Experiments were conducted at different sites to determine the feasibility of interseeding $x$ tillage combinations to improve stands of Tifton 9 bahiagrass.

\section{Materials and Methods}

Experimental sites used in this research were previously planted in 1993 (upland site) and 1995 (lowland site) to determine establishment response of Tifton 9 bahiagrass to several planting variables and seed treatments (Gates and Mullahey 1997, Gates and Dewald 1998). Upon completion of these experiments, relatively open 2- or 3-year old stands provided an opportunity to examine treatments which might enhance stand coverage. The 2 sites at the Coastal Plain Experiment Station in Tifton, Ga. (31 $26^{\circ} \mathrm{N}, 83^{\circ} 35^{\prime}$ ' W) were a droughty upland (Dothan loamy sand; fine-loamy siliceous thermic Plinthic Kandiudults) with unfavorable surface soil moisture during much of the growing season and a lowland site (Alapaha sand; loamy, siliceous, thermic Arenic Plinthic Paleaquults) where heavier soil texture and physiographic position resulted in more favorable surface soil moisture (Gates and Dewald 1998).

Four treatment combinations of tillage and reseeding were evaluated at both sites: 1) rototilling to a depth of $\sim 100 \mathrm{~mm}$, resulting in nearly complete sod destruction, followed by seeding, 2) shallow disking, resulting in disturbance of less than half of the sod, followed by seeding, 3 ) interseeding alone, and 4) undisturbed, non-seeded control. Six replications were planted on 10 April 1995 at the upland site. At the lowland site, 4 replications were planted 13 April 1998. All planting was done at the same seeding rate $(5.6 \mathrm{~kg}$ $\mathrm{ha}^{-1}$ ) using a 7-row plot drill equipped with fluted coulters and double disk openers spaced $178 \mathrm{~mm}$ apart. Soil conditions at the time of planting at both sites allowed penetration and seed placement at a depth of $\sim 15 \mathrm{~mm}$. A firm seedbed was provided by driving a tractor across the plots before and immediately after planting. Nitrogen fertilizer was applied $\left(56 \mathrm{~kg} \mathrm{ha}^{-1}\right)$ once in spring at each site. Soil tests indicated other nutrients were adequate. Plots were mowed periodically during the growing season. No herbicide applications were made. Treatments were assigned to plots without regard to previous treatment, encompassing several plots from previous experiments. Plot size was $1.5 \times 20 \mathrm{~m}$ at the upland site and $1.5 \times 9.1 \mathrm{~m}$ at the lowland site.

Initial stand ratings were taken at the upland site during the week preceding replanting treatments. On 3 April 1995, presence or absence of bahiagrass was recorded in each 100 square $\mathrm{cm}$ unit of a 1 $\mathrm{m} \times 1 \mathrm{~m}$ sampling quadrat, using 9 randomly placed quadrats per plot. Stand ratings were repeated the following spring, 11 May 1996, to evaluate change in stand ratings. At the lowland site the same procedure was used except that 5 quadrats per plot were used. Initial stands were evaluated 7 April 1998 and final stands on 10 May 1999.

Initial and final stand ratings and the change in rating were analyzed using analysis of covariance implemented using SAS GLM (SAS 1998). The statistical model evaluated final stand ratings, adjusted using initial stand as a covariate. Treatment means were compared using single degree of freedom contrasts. Tillage treatments (rototilling and disking) were first contrasted with treatments without tillage (control and interseeding). Two additional contrasts compared the 2 treatments within each tillage category (rototilling vs. disking; control vs. interseeding).

\section{Table 1. Least squares means and F-test probabilities associated with single d.f. contrasts for final basal occupation of Tifton 9 bahiagrass stands following tillage and reseeding treatments at 2 sites near Tifton, Ga.}

\begin{tabular}{lcc}
\hline \hline & $\begin{array}{c}\text { Dry Upland } \\
\text { Sreatment }\end{array}$ & Moist Lowland \\
Site & Site \\
\hline Interseed & 78 & 60 \\
Disk & 68 & 52 \\
Rototill & 55 & 78 \\
Control & 80 & 59 \\
Contrast & ---------- \\
$\quad$ Tillage vs None & 0.0001 & 0.62 \\
$\quad$ Disk vs Rototill & 0.007 & 0.10 \\
$\quad$ Interseed vs Control & 0.63 & 0.94 \\
\hline
\end{tabular}

Number of 100 x $100 \mathrm{~mm}$ squares occupied by bahiagrass out of 100 possible within $1 \mathrm{~m}^{2}$ quadrat.
Bahiagrass stands were 2 years old at the upland site and 3 years old at the lowland site when treatments were initiated. Basal occupation averaged $61 \%$ initially at the upland site but only $28 \%$ at the lowland site. Final stands (averaging $70 \%$ at the upland site; $62 \%$ at the lowland site) were similar, indicating more rapid increase in cover with more favorable soil moisture conditions at the lowland site. Final stand occupation at the upland site was lower $(\mathrm{P}<0.05)$ for treatments including tillage compared to those without tillage (Table 1). A decrease in basal occupation due to rototilling indicated lower $(\mathrm{P}<0.05)$ final stands compared with disking. No difference $(\mathrm{P}>0.05)$ in final basal occupation resulted from interseeding or control. The similarity in response of the latter treatments strongly indicates that drilling with $5.6 \mathrm{~kg} \mathrm{ha}^{-1}$ of additional seed made no contribution to stand improvement at this site.

At the lowland site (Table 1) there was a marked improvement in stands, however, no differences were detected between any of the treatments and the control. The positive change observed for rototilling plus interseeding at the lowland site contrasted with the response to this treatmen at the upland site. More favorable soil moisture holding capacity and greater pring precipitation in 1998 compared with 1995 (Fig. 1) may have contributed to more successful establishment of newly planted seed.

Tifton 9 bahiagrass stands, relatively free of perennial weeds, with basal occupation ranging between 20 and $60 \%$, as evaluated in this research, did not benefit from any combination of tillage and/or reseeding. Even the most open stands had several established plants within a $1.0 \mathrm{~m}^{2}$ quadrat. Under these conditions, the best substantial sod destruction, resulting in 
recommendation is to allow stands to fill in from established plants. Interplant distances of less than $1 \mathrm{~m}$ established an environment in which seedlings apparently were unable to compete successfully enough with established plants to improve the rate of stand coverage. However, it is also likely that, at the scale of a field planting, if interplant spaces approach a few meters, it will require several years for the stand to become completely covered without introducing additional seed.

Tifton 9 has a more erect morphology than the more widely used cultivar 'Pensacola' (Gates et al. 1999). Werner and Burton (1991) found that a single Pensacola seedling could occupy an area 1.2 times that of a Tifton 9 seedling in a single growing season in a spaced planting. Our observations suggest that once Pensacola seedlings are established, a stand may cover more rapidly than with Tifton 9.

The slow rate of bahiagrass establishment and the difficulty in improving stands after initial planting underscores the need to develop strategies to improve the reliability of rapid establishment of bahiagrass from seed. This is especially critical with Tifton 9 to capitalize on the potential yield advantages of this improved cultivar (Burton 1989, Gates et al. 1999).

\section{Literature Cited}

Bahler, C.C., L.E. Moser, T.S. Griffin, and K.P. Vogel. 1990. Warm-season grass establishment as affected by post-planting atrazine application. J. Range Manage. 43:421-424.

Beaty, E.R. and J.D. Powell. 1978. Growth and management of Pensacola bahiagrass. J. Soil Water Conserv. 33:191-192.

Beckman, J.J., L.E. Moser, Keith Kubik and S.S. Waller. 1993. Big bluestem and switchgrass establishment as influenced by seed priming. Agron. J. 85:199-202.

Burton, G.W. 1989. Registration of 'Tifton 9' Pensacola bahiagrass. Crop Sci. 29:1326.

Gates, R.N. and C.L. Dewald.1998. Establishment of 'Tifton 9' bahiagrass in response to planting date and seed coat removal. Agron. J. 90:462-465.

Gates, R.N. and J.J. Mullahey. 1997. Influence of seeding variables on 'Tifton 9' bahiagrass establishment. Agron. J. 89:134-139.

Gates, R.N., G.M. Hill and G.W. Burton. 1999. Response of selected and unselected bahiagrass populations to defoliation. Agron. J. 91:878-795.

Hintz, R.L., K.R. Harmoney, K.J. Moore, J.R. George, and E.C. Brummer. 1998. Establishment of switchgrass and big bluestem in corn with atrazine. Agron. J. 90:591-596.

Masters, R.A. 1995. Establishment of big bluestem and sand bluestem cultivars with metalachlor and atrazine. J. Range Manage. 87:592-596.
Masters, R.A., K.P. Vogel, P.E. Reece, and D. Bauer. 1990. Sand bluestem and prairie sandreed establishment. J. Range Manage. 43:540-544.

McKenna, J.R. and D.D. Wolf. 1990. No-till switchgrass establishment as affected by limestone, phosphorus, and carbofuran. J. Prod. Agr. 3:475-479.

Ries, R.E. and L. Hofmann. 1996. Perennial grass establishment in relationship to seeding dates in the northern Great Plains. J. Range Manage. 49:504-508.

SAS Institute. 1998. SAS/STAT guide for personal computers, Ver. 7. SAS Inst., Cary, N.C.

Vassey, T.L., J.R. George, and R.E. Mullen. 1985. Early-, mid-, and late-spring establishment of switchgrass at several seeding rates. Agron. J. 77:253-257.

Vogel, K.P. 1987. Seeding rates for establishing big bluestem and switchgrass with preemergence atrazine applications. Agron. J. 79:509-512.

Werner, B.K. and G.W. Burton. 1991. Changes in morphology and yield of Pensacola bahiagrass due to recurrent restricted phenotypic selection for yield. Crop Sci. 31:48-50.

West, S.H. and F.J. Marousky. 1989. Mechanism of dormancy in Pensacola bahiagrass. Crop Sci. 29:787-791.

Williams, R.C. and B.C. Webb. 1958. Seed moisture relationships and germination behavior of acid-scarified bahiagrass seed. Agron. J. 50:235-237. 